\title{
Perancangan Sistem Informasi Bank Sampah Menggunakan Framework Codeigniter dan Bootsrap dengan Metode Prototype
}

\author{
Abu Sopian ${ }^{1}$, Agus Wiyatno ${ }^{2}$ \\ ${ }^{1}$ Teknik Informatika, Universitas Mohammad Husni Thamrin Jakarta \\ ${ }^{2}$ Sistem Informasi, Sekolah Tinggi Manajemen Informatika dan Komputer Nusa Mandiri Jakarta \\ ianprosia2@gmail.com¹, guscvn@gmail.com²
}

\begin{abstract}
Abstrak
Bank sampah adalah suatu sistem pengelolaan sampah kering secara kolektif yang mendorong masyarakat untuk berperan serta aktif di dalamnya. Sistem ini akan menampung, memilah, dan menyalurkan sampah bernilai ekonomi pada pasar sehingga masyarakat mendapatkan keuntungan ekonomi dari menabung sampah. Bank Sampah RW.04 Kelurahan Cipinang Besar Selatan, Kecamatan Jatinegara Kota Jakarta Timur adalah suatu Bank yang digunakan untuk mengumpulkan sampah warga yang sudah dipilah. Para nasabah Bank Sampah dapat menabung berupa sampah sesuai dengan jenis sampah dan harga perkilo nya yang ditetapkan lalu ditimbang berat sampahnya sehingga menjadi tabungan berupa uang. Hasil dari pengumpulan sampah yang sudah ditimbang akan dicatat dalam tabungan nasabah. Sedangkan sampah akan disetorkan ketempat agen pengepul sampah atau dapat dijual dipasar. Saat ini dalam pengelolaannya belum menggunakan sistem informasi sehingga sering terjadi permasalahan dalam transaksi dan laporan bulanan, dan sering terjadi tertukarnya jumlah timbangan beserta jenis sampahnya. Untuk mengatasi permasalahan tersebut, maka penulis bermaksud memberikan solusi dengan merancang sebuah Sistem Informasi Bank Sampah untuk mengolah data tabungan nasabah menggunakan framework codeigniter dan bootstrap dengan metode prototype. Hasil dari perancangan Sistem Informasi Bank Sampah ini adalah kualitas sistem sangat baik untuk pencatatan transaksi dan laporan bulanan lebih efektif.
\end{abstract}

Kata Kunci - Sistem Informasi, Bank Sampah, Framework Codeigniter, Framework Bootstrap, Prototype

\begin{abstract}
Abstrak
The garbage bank is a collective dry waste management system that encourages the community to participate actively in it. This system will accommodate, sort, and distribute waste of economic value to the market so that people can get economic benefits from saving waste. The garbage bank RW.04 Cipinang Besar Selatan Subdistrict, Jatinegara District, East Jakarta City is a bank that is used to collect sorted waste from residents. The garbage bank customers can save in the form of waste according to the type of waste and the price per kilo is set then weigh the waste so that it becomes savings in the form of money. The results of the weighed waste collection will be recorded in the customer's savings. Meanwhile, the waste will be deposited to the garbage collector agency or it can be sold in the market. Currently, the management has not used an information system so that there are often problems in transactions and monthly reports, and the number of scales and types of waste is often confused. To overcome this problem, the authors intend to provide a solution by designing a Garbage bank Information System to process customer savings data using a codeigniter framework and bootstrap with the prototype method. The result of the design of the Garbage bank Information System is that the system quality is very good for recording transactions and monthly reports more effectively.
\end{abstract}

Keywords - Information Systems, Garbage Bank, Codeigniter Framework, Bootstrap Framework, Prototype 


\section{PENDAHULUAN}

Bank sampah adalah suatu sistem pengelolaan sampah kering secara kolektif yang mendorong masyarakat untuk berperan serta aktif di dalamnya.

Sistem ini akan menampung, memilah, dan menyalurkan sampah bernilai ekonomi pada pasar sehingga masyarakat mendapatkan keuntungan ekonomi dari menabung sampah [1]. Saat ini, salah satu yang menjadi permasalahan di lingkungan masyarakat adalah sampah rumah tangga. Kurang efektifnya dalam pengelolaan sampah rumah tangga pada lingkungan masyarakat seperti terjadinya penumpukan sampah yang tidak terkendali, pembakaran sampah, pembuangan sampah di sungai-sungai atau di gorong-gorong adalah menjadi permasalahan yang serius yang harus ditanggulangi oleh pemerintah beserta masyarakat secara bersama untuk menghasilkan lingkungan yang sehat dan bersih. Dengan kondisi seperti ini, sebagian besar di wilayah Indonesia khususnya diperkotaan telah banyak mendirikan Bank Sampah untuk mengelola sampah rumah tangga yang bertujuan menghasilkan lingkungan yang sehat dan bersih serta menjadikan nilai tambah yang bernilai ekonomis bagi warga sekitar Bank Sampah.

Bank Sampah RW.04 Kelurahan Cipinang Besar Selatan Kecamatan Jatinegara Kota Jakarta Timur, saat ini belum memiliki sebuah sistem informasi untuk pencatatan tabungan nasabah. Hanya menggunakan buku catatan manual dalam menyimpan data tabungan nasabah dirasa belum optimal dalam pencatatan dan penyampaian informasi jumlah tabungan kepada nasabah Bank Sampah, sehingga sering terjadi permasalahan dalam transaksi dan laporan bulanan, dan sering terjadi tertukarnya jumlah timbangan beserta jenis sampahnya serta kurang baiknya dalam penyimpanan data untuk menanggulangi data nasabah beserta jumlah tabungannya.

Berdasarkan dari latar belakang tersebut dan mengingat pentingnya permasalahan diatas, maka perlu dilakukan Perancangan Sistem Informasi Bank Sampah Menggunakan Framework Codeigniter dan Boorstrap dengan Metode Prototype untuk dapat mengurangi permasalah yang sering terjadi seperti yang disebutkan diatas sehingga pencatatan tabungan nasabah Bank Sampah lebih baik. Sistem Informasi merupakan sebuah sistem yang kompleks, bukan hanya komputer saja yang bekerja (beserta software dan hardware di dalamnya), namun juga manusia (dengan brainware yang dimiliki), manusia (pengguna/aktor) dalam hal ini menggunakan seluruh ide, pemikiran, untuk dituangkan ke dalam sistem informasi yang digunakan [2]. Dari definisi tersebut dapat disimpulkan bahwa sistem informasi mencakup komponen (manusia, komputer, teknologi informasi, dan prosedur kerja), ada sesuatu yang diproses (data menjadi informasi), dan dimakasudkan untuk mencapai suatu sasaran atau tujuan. Dalam Perancangan Sistem Informasi Bank Sampah ini, penulis menggunakan framework codeigniter tujuannya adalah memungkinkan anda untuk mengembangkan proyek lebih cepat daripada yang anda bisa jika anda menulis kode dari awal, dengan menyediakan serangkaian perpustakaan yang kaya untuk tugas-tugas yang biasanya dibutuhkan, serta antarmuka yang sederhana dan struktur logis untuk mengakses perpustakaan ini.

Codelgniter memungkinkan anda secara kreatif fokus pada proyek anda dengan meminimalkan jumlah kode yang diperlukan untuk tugas yang diberikan [3]. Sedangkan merancang dengan bootsrap untuk bagian pengembangan front-end website lebih cepat. Bootstrap adalah toolkit sumber terbuka untuk dikembangkan dengan HTML, CSS, dan JS [4]. Serta perancangan sistem informasi menggunakan metode prototype dengan tujuan agar lebih optimal mengingat waktu yang singkat serta jumlah anggota tim penelitian yg sedikit. Prototype adalah suatu pendekatan yang digunakan jika pemakai hanya mendefenisikan objektif umum dari sistem tanpa merinci kebutuhan input, pemrosesan dan outputnya, sementara pengembang tidak begitu yakin akan efesiensi algoritma, adaptasi sistem operasi, atau bentuk antarmuka manusia-mesin yang harus diambil [5].

Esensi dari metode prototype adalah mendefinisikan objektif secara keseluruhan dan mengidentifikasi kebutuhan yang sudah diketahui. Melakukan perancangan secara cepat sebagai 
dasar untuk membuat prototype. Menguji coba dan mengevaluasi prototype dan kemudian melakukan penambahan dan perbaikan-perbaikan terhadap prototype yang sudah dibuat. Keuntungan dari model prototype adalah umpan balik langsung dari pihak pengelola bank sampah RW.04 Kel. Cipinang Besar Selatan, penulis mendapatkan umpan balik segera setelah menghasilkan prototype dan menunjukkan kepada stakeholder/ pihak pengelola bank sampah RW.04 Kel. Cipinang Besar Selatan.

\section{METODE PENELITIAN}

Metode penelitian dalam perancangan sistem informasi Bank Sampah RW.04 Kel. Cipinang Besar Selatan yang dilakukan terdiri dari tahapantahapan yaitu: 1).Identifikasi Masalah, 2).Perumusan Masalah, 3).Pengumpulan Data, 4).Rancangan Pengembangan Sistem, 5).Penyimpulan Hasil.

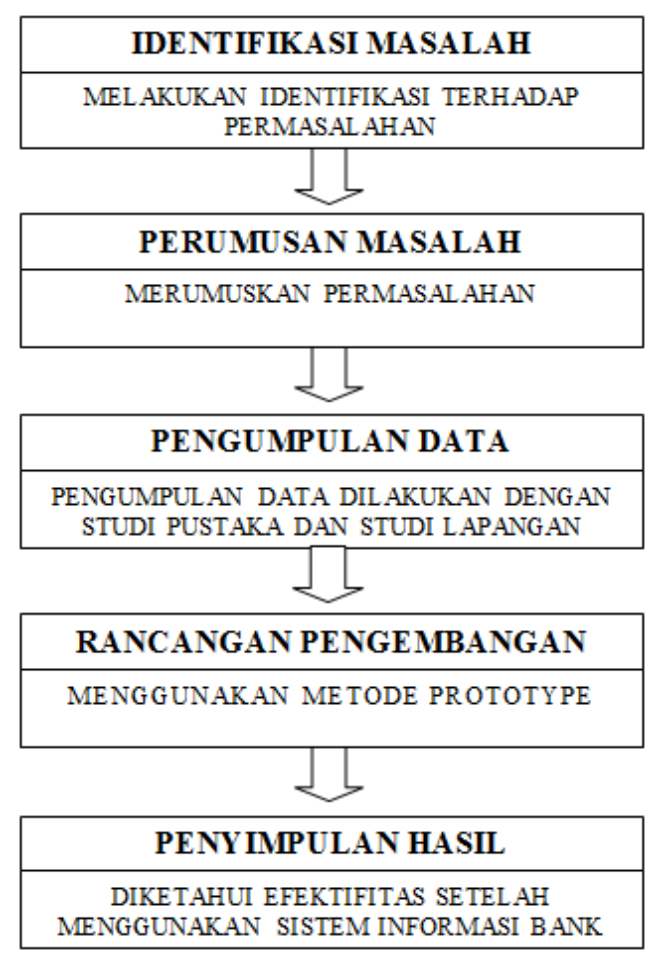

Gambar 1. Tahapan Penelitian
1). Identifikasi Masalah

Sesuai dengan latar belakang penelitian maka dapat diidentifikasi permasalahan yaitu Bank Sampah RW.04 dalam pengelolaannya belum menggunakan sistem informasi sehingga sering terjadi permasalahan dalam transaksi dan laporan bulanan, dan sering terjadi tertukarnya jumlah timbangan beserta jenis sampahnya serta kurang baiknya dalam penyimpanan data untuk menanggulangi data nasabah beserta jumlah tabungannya.

\section{2). Perumusan Masalah}

Dari identifikasi masalah maka dapat dirumuskan permasalahan sebagai berikut:

a) Seberapa besar tingkat efisiensi dan efektifitas yang dihasilkan dari pemanfaatan sistem informasi bank sampah?

\section{3). Pengumpulan Data}

Dalam tahapan pengumpulan data penelitian ini digunakan teknik pengumpulan data yang terdiri dari studi pustaka dan studi lapangan. Data-data yang berhubungan dengan kajian penelitian, bersumber dari:

a) Studi Pustaka (Library Research)

Yaitu suatu metode yang dilakukan dengan cara mengumpulkan, membaca, dan mempelajari data-data yang ada dari berbagai media, seperti buku-buku, hasil karya tulis, jurnal-jurnal penelitian, atau artikel-artikel dari internet yang berhubungan dengan masalah yang dibahas.

b) Studi Lapangan (Field Research)

Yaitu pengumpulan data-data dengan cara wawancara dan observasi langsung pada Bank Sampah yang beralamat di Jalan. Panca Warga IV, RW.04. Kel. Cipinang Besar Selatan, Kec. Jatinegara Kota Jakarta Timur 
4). Rancangan Pengembangan Sistem

Tahapan penelitian dalam pengembangan sistem menggunakan metode prototype pada gambar 2 dibawah ini:



Gambar 2. Metode Pengembangan Sistem dengan Protoype

a) Communication.

Tahapan yang dimulai dengan dilakukannya komunikasi antara tim pengembang sistem informasi bank sampah dengan pihak pengelola bank sampah RW.04 Kel. Cipinang Besar Selatan.

b) Quick Plan.

Tahapan dimana tim pengembang bertemu dengan stakeholder/ pihak pengelola bank sampah RW.04 Kel. Cipinang Besar Selatan untuk mendefinisikan sasaran keseluruhan sistem informasi bank sampah, mengidentifikasi spesifikasi kebutuhan yang diketahui, dan menggambarkan definisi lebih jauh pada iterasi selanjutnya.

c) Modeling Quick Design.

Tahapan pembuatan prototipe direncanakan dengan cepat, dan pemodelan dilakukan.

d) Construction of Prototype.

Tahapan penyerahan prototipe kepada stakeholder/ pihak pengelola bank sampah RW.04 Kel. Cipinang Besar
Selatan untuk dievaluasi, dan memberikan umpan balik yang digunakan untuk persyaratan lebih lanjut.

e) Deployment, Delivery \& Feedback.

Tahapan pengulangan proses iterasi apabila prototipe diperbaiki, dimana mencari umpan balik dari stakeholder terhadap prototype yang dirancang. Apabila ada perbaikan maka dilakukan perbaikan dengan pengulangan proses iterasi prototype.

5). Penyimpulan Hasil.

Yaitu tahapan yang dilakukan untuk untuk menyimpulkan hasil dari penelitian dengan mengukur tingkat efisiensi dan efektifitas yang dihasilkan dari pemanfaatan sistem informasi bank sampah.

\section{HASIL DAN PEMBAHASAN}

A. Perancangan Sistem

Dari analisis sistem berjalan maka dapat dilihat ada beberapa transaksi yang dilakukan yaitu :

1.1. Admin :

1. Login untuk mengakses Sistem Informasi Bank Sampah.

2. Kelola data nasabah untuk mengelola data nasabah dengan input, update dan delete.

3. Kelola data sampah untuk mengelola data sampah dengan input, update dan delete.

4. Kelola data transaksi untuk mengelola data transaki nasabah bank sampah dengan input, update dan delete.

5. Laporan untuk kelola laporan.

1.2. Nasabah:

1. Login untuk mengakses Sistem Informasi Bank Sampah.

2. View profile untuk mengelola profile nasabah.

3. View data sampah untuk melihat jenis sampah.

4. View riwayat transaksi untuk melihat riwayat transaksi.

1.3. Kepala Bank Sampah :

1. Login untuk mengakses Sistem Informasi Bank Sampah. 
2. View laporan untuk melihat laporan.

\section{B. Implementasi Sistem}

Pada tahapan ini dilakukan pemodelan data, pembuatan Use Case Diagram, Activity Diagram, Entity Relationship Diagram dan pembuatan kode program serta perancangan Databasel dan perancangan aplikasi. Berikut adalah tahapantahapan desain diantaranya :

\subsection{Use Case Diagram}

Use case diagrarm dirancang setelah tahapan analisis sistem berjalan dapat dilihat pada gambar 3 dibawah ini :

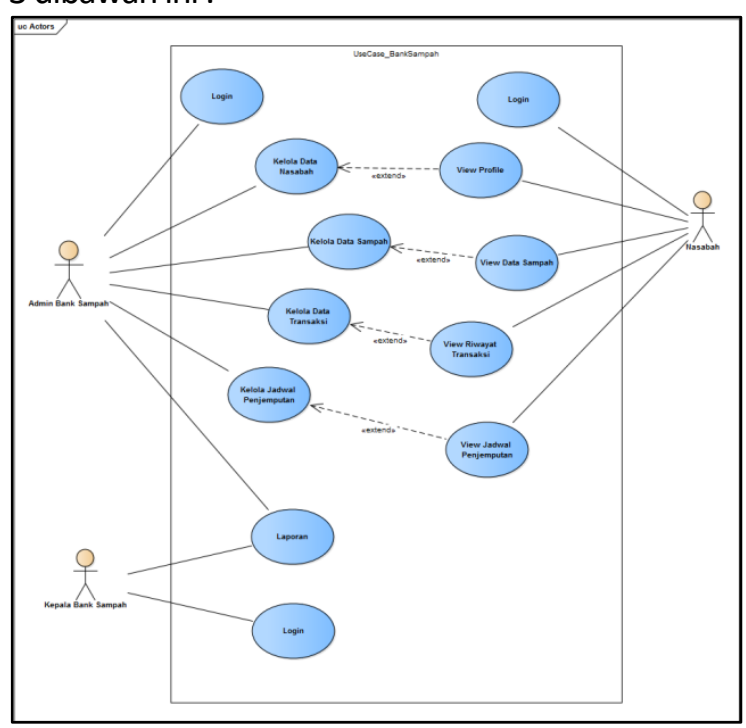

Gambar 3. Use Case Diagram Sistem Informasi Bank Sampah

Use case diagram Sistem Informasi Bank Sampah terdiri dari tiga aktor utama yaitu : Admin, Nasabah dan Kepala Bank Sampah. Admin dapat melakukan login, kelola data nasabah, sampah dan transaksi serta membuat laporan. Nasabah dapat melakukan login, melihat profile, jenis sampah dan transaksi. Sedangkan kepala bank sampah dapat melakukan login dan melihat laporan transaksi.

\subsection{Activity Diagram}

Diagram ini dibuat berdasarkan aktivitas yang terjadi dalam sistem berjalan. Diagram aktivitas dalam sistem informasi Bank Sampah diantaranya diagram aktivitas login, kelola data sampah, kelola data nasabah, kelola data transaki kelola jadwal penjemputan dan kelola laporan. Diagram aktivitas dapat dilihat pada gambar dibawah berikut ini:

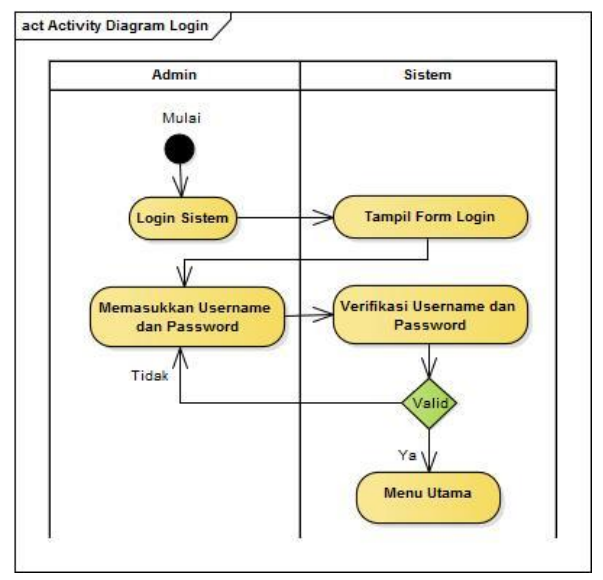

Gambar 4. Activity Diagram Login

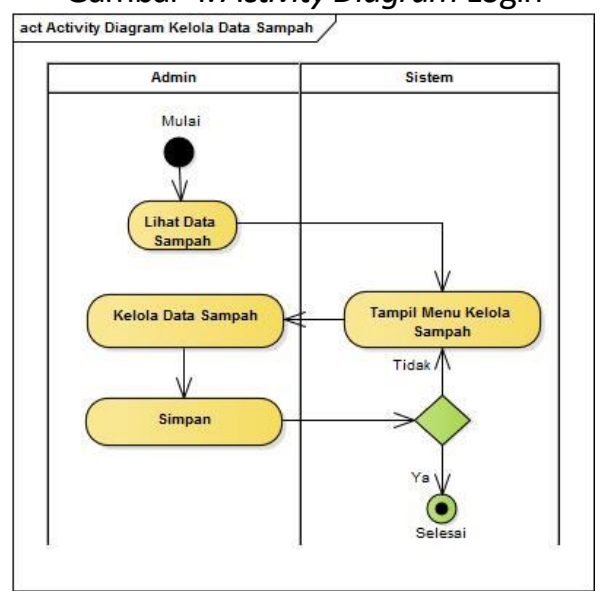

Gambar 5. Activity Diagram Kelola Data Sampah



Gambar 6. Activity Diagram Kelola Data Nasabah 


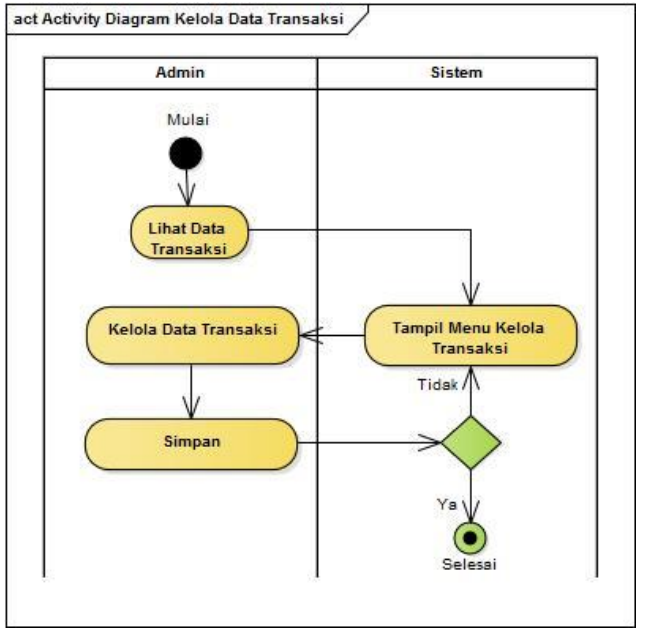

Gambar 7. Activity Diagram Kelola Data Transaksi

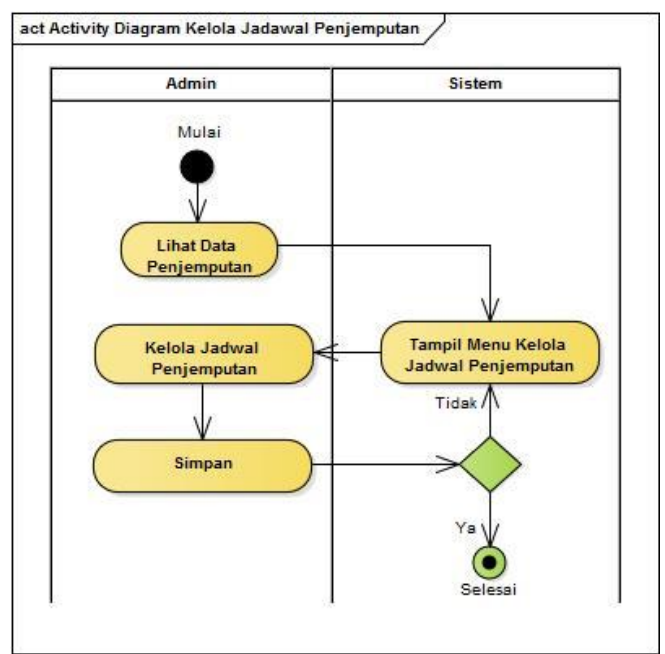

Gambar 8. Activity Diagram Kelola Data Jadwal Penjemputan

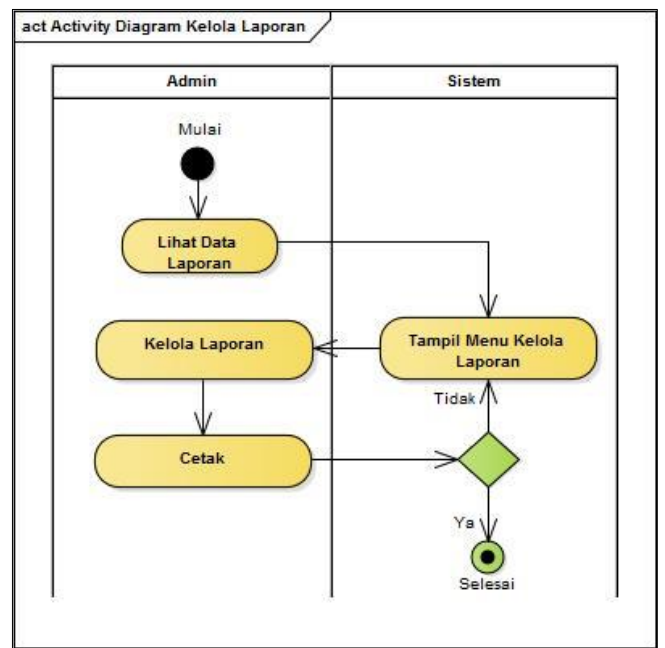

Gambar 9. Activity Diagram Kelola Data Laporan

\subsection{Entity Relationship Diagram (ERD)}

Entity Relationship Diagram (ERD) berhubungan dengan data flow Sistem Informasi Bank Sampah untuk memvisualisasikan hubungan data berupa entitas untuk menkonstruksi database berelasi. Dibawah ini adalah Entity Relationship Diagram (ERD) sistem informasi bank sampah :

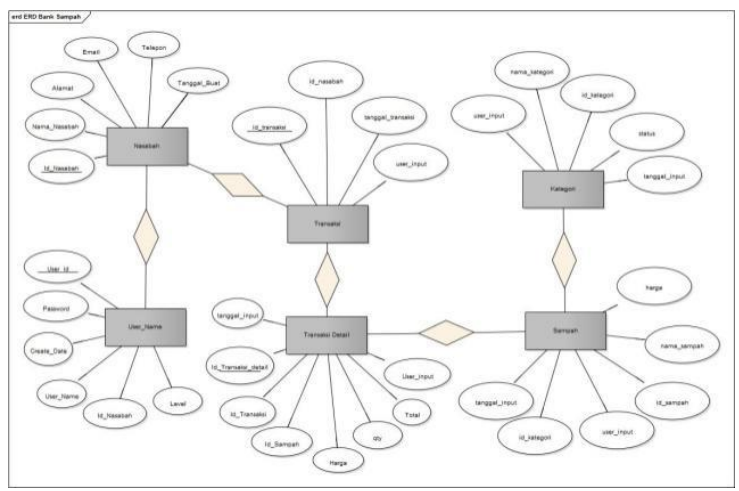

Gambar 10. Entity Relationship Diagram Sistem Informasi Bank Sampah

\subsection{Perancangan Database}

Database yang digunakan dalam perancangan sistem informasi bank sampah ini yaitu menggunakan database MySQL. Dengan hasil desain sebagai berikut dapat dilihat pada gambar 11 :

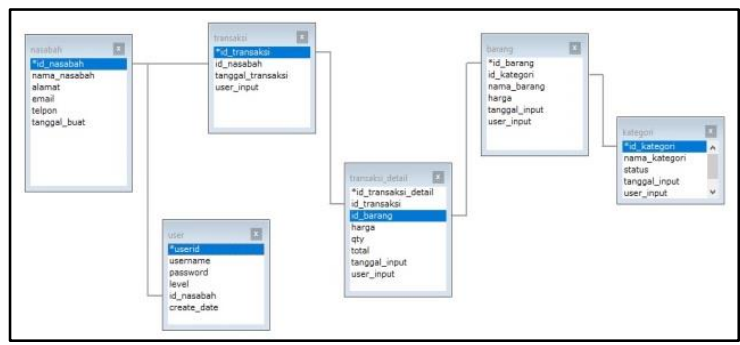

Gambar 11. Database Sistem Informasi Bank Sampah

\subsection{Perancangan Aplikasi}

Perancangan aplikasi adalah rancangan keluaran yang merupakan rancangan desain tampilan dari sistem informasi bank sampah yang informasinya berasal dari pembuat, kemudian informasi tersebut disusun dan ditampilkan kepada 
pengguna. Dalam merancang tampilan, rancangan harus mudah digunakan oleh pengguna agar pengguna dapat dengan mudah menggunakan fitur yang ada pada sistem informasi bank sampah tersebut. Kemudahan akan mempengaruhi efektivitas dan efisiensi pengguna dalam menjalankan pekerjaanya.

Berikut ini adalah laman proses login sistem informasi bank sampah dapat dilihat pada gambar 12.

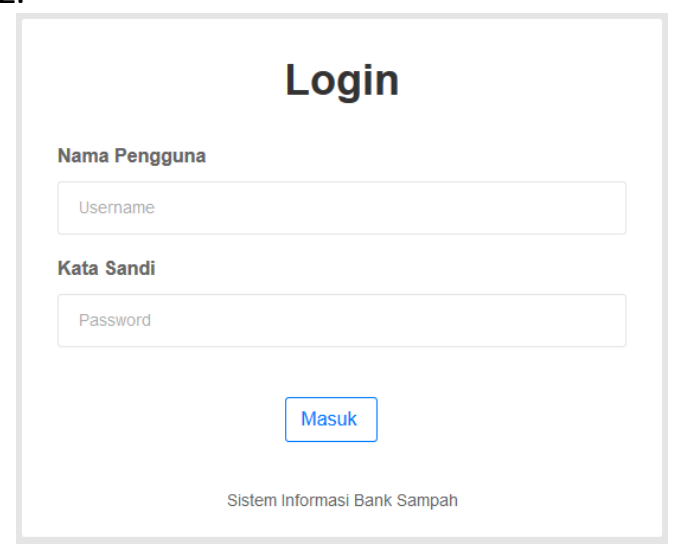

Gambar 12. Laman Proses Login

Setelah user sukses dalam proses login dengan cara mengisikan username dan password, maka akan tampil halaman utama. Berikut adalah menu utama dari admin.

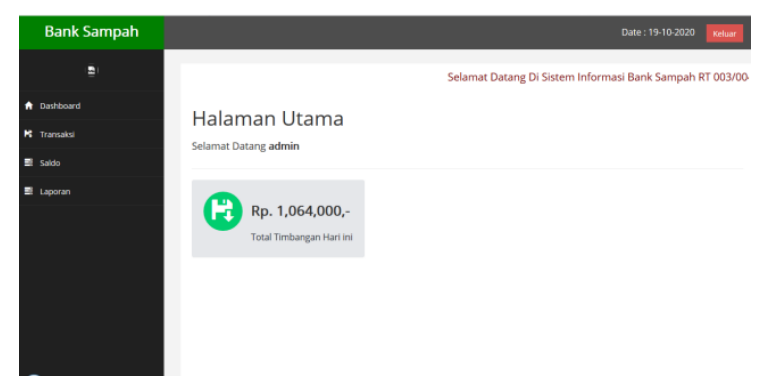

Gambar 13. Laman Menu Utama

Admin dapat melakukan pengelolaan data transaksi pada sistem informasi bank sampah dapat dilihat pada gambar 14 dan 15 berikut ini:

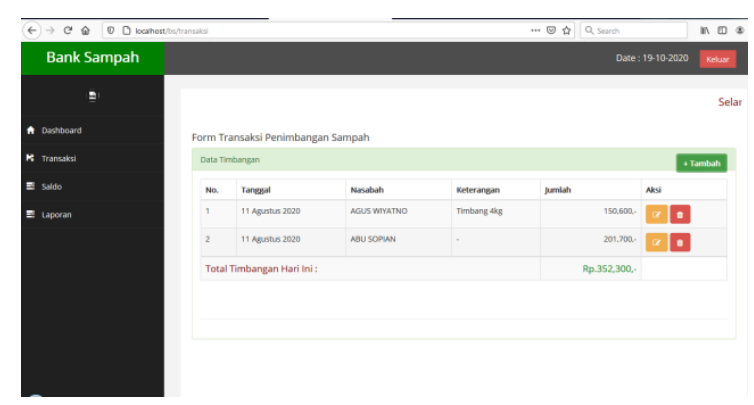

Gambar 14. Laman Kelola Transaksi

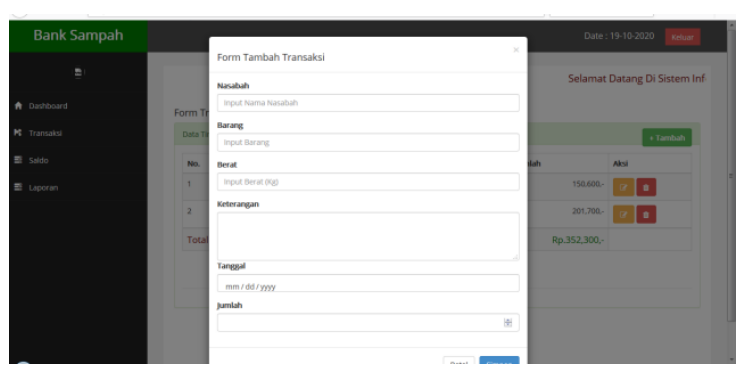

Gambar 15. Laman Kelola Transaksi

Admin juga dapat mengelola data laporan pada sistem informasi bank sampah setelah melakukan pengelolaan data transaksi. Laman kelola laporan dapat dilihat pada gambar 16 beriktu ini:

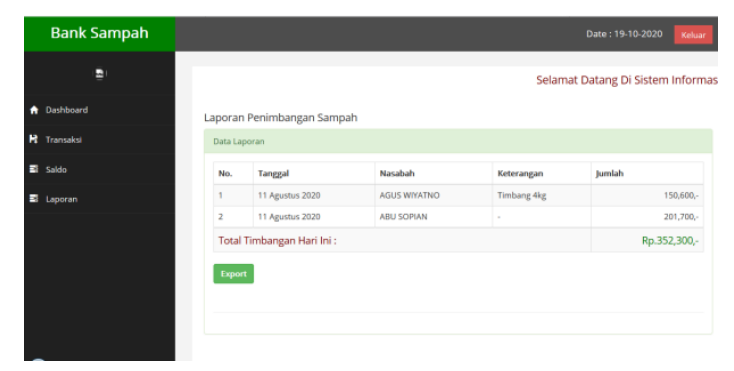

Gambar 16. Laman Kelola Laporan

\section{Pengujian Sistem}

Pengujian dilakukan dengan pendekatan Black Box Testing dan ISO 9126. Black box testing yaitu menguji perangkat lunak dari segi spesifikasi fungsional tanpa menguji desain dan kode program. Pengujian yang dilakukan oleh pengembang perangkat lunak untuk mendapatkan set kondisi masukkan yang sepenuhnya akan melaksanakan semua persyaratan fungsional suatu program. 
Pengujian dengan Black Box Testing yaitu pengujian fungsional tanpa melihat alur eksekusi program, namun cukup dengan memperhatikan apakah setiap fungsi sudah berjalan dengan baik. Fungsi-fungsi yang diuji adalah proses login, tombol-tombol menu dalam sistem informasi bank sampah.

Berikut hasil uji coba fitur sistem informasi bank sampah dari segi spesifikasi fungsional tanpa menguji desain dan kode program.

Tabel 1. Hasil Uji Coba Fitur Sistem Informasi Bank Sampah

\begin{tabular}{|c|l|c|}
\hline No & \multicolumn{1}{|c|}{ Fitur } & Keterangan \\
\hline 1 & Login & Barjalan Baik \\
\hline 2 & Menu Utama & Barjalan Baik \\
\hline 3 & Menu Kelola Transaksi & Barjalan Baik \\
\hline 4 & Menu Kelola Data Sampah & Barjalan Baik \\
\hline 5 & $\begin{array}{l}\text { Menu Kelola Data } \\
\text { Nasabah }\end{array}$ & Barjalan Baik \\
\hline 6 & Menu Kelola Jadwal & Barjalan Baik \\
\hline 7 & Menu Laporan & Barjalan Baik \\
\hline 8 & Menu View Profile & Barjalan Baik \\
\hline 9 & Menu View Data Sampah & Barjalan Baik \\
\hline 10 & $\begin{array}{l}\text { Menu View Riwayat } \\
\text { Transaksi }\end{array}$ & Barjalan Baik \\
\hline
\end{tabular}

Sedangkan pengujian dengan ISO 9126 merupakan pengujian dengan salah satu framework standar internasional yang digunakan untuk menguji kualitas sistem yang dibuat oleh International Organization for Standarization (ISO) dan International Electrotecnichal Commission (IEC). Pengujian dengan ISO 9126 ini bertujuan untuk mendefinisikan kualitas produk [6].

Pengujian dengan ISO 9126 menggunakan 6 aspek yaitu, Functionality terdiri dari 4 pertanyaan, Reliability terdiri dari 3 pertanyaan, Usability terdiri dari 4 pertanyaan, Efficiency terdiri dari 2 pertanyaan, Maintainability terdiri dari 4 pertanyaan, Portability terdiri dari 2 pertanyaan dan masing-masing aspek diuji aspek functionality dengan parameter skala likert.
Tabel 2. Skala Likert

\begin{tabular}{|c|l|c|}
\hline No & \multicolumn{1}{|c|}{ Kategori } & Skala \\
\hline 1 & Sangat Baik & 4 \\
\hline 2 & Baik & 3 \\
\hline 3 & Kurang Baik & 2 \\
\hline 4 & Sangat Sangat Baik & 1 \\
\hline
\end{tabular}

1. Pengujian aspek functionality

Dasar pengujian kualitas sistem informasi aspek functionality terdiri dari 4 pertanyaan dengan skala likert dilakukan perhitungan sebagai berikut.

1. Sangat Baik $=10$ Responden $\times 4$ skala $\times 4$ pertanyaan $=121-160$

2. Baik $=10$ Responden $\times 3$ skala $\times 4$ pertanyaan $=$ $81-120$

3. Kurang Baik $=10$ Responden $\times 2$ skala $\times 4$ pertanyaan $=41-80$

4. Sangat Kurang Baik $=10$ Responden $x 1$ skala $x$ 4 pertanyaan $=0-40$

Tabel 3. Skala Likert Functionality

\begin{tabular}{|c|l|c|}
\hline No & \multicolumn{1}{|c|}{ Kategori } & Skala \\
\hline 1 & Sangat Baik & $121-160$ \\
\hline 2 & Baik & $81-120$ \\
\hline 3 & Tidak Baik & $41-80$ \\
\hline 4 & Sangat Tidak Baik & $0-40$ \\
\hline
\end{tabular}

Berikut hasil pengujian dari aspek Functionality ISO 9126 dari 10 responden sistem informasi bank sampah. Dari hasil pengujian mendapat nilai total skala 152 yang berarti hasil pengujian functionality termasuk kisaran skala 121-160 yaitu sangat baik.

Tabel 4. Hasil Pengujian Aspek Functionality

\begin{tabular}{|c|c|c|c|c|c|}
\hline Responden & P 1.1 & P 1.2 & P 1.3 & P 1.4 & Total \\
\hline 1 & 4 & 4 & 3 & 4 & 15 \\
\hline 2 & 4 & 4 & 4 & 4 & 16 \\
\hline 3 & 4 & 4 & 4 & 4 & 16 \\
\hline 4 & 4 & 4 & 3 & 4 & 15 \\
\hline 5 & 3 & 4 & 4 & 3 & 14 \\
\hline 6 & 4 & 3 & 4 & 4 & 15 \\
\hline 7 & 4 & 4 & 3 & 4 & 15 \\
\hline 8 & 4 & 4 & 4 & 4 & 16 \\
\hline 9 & 4 & 4 & 3 & 3 & 14 \\
\hline 10 & 4 & 4 & 4 & 4 & 16 \\
\hline \multicolumn{7}{|r|}{} \\
\hline
\end{tabular}

2. Pengujian aspek reliability

Berikutnya dasar pengujian kualitas sistem informasi aspek Reliability terdiri dari 3 pertanyaan dengan skala likert dilakukan perhitungan sebagai berikut. 
1. Sangat Baik $=10$ Responden $\times 4$ skala $\times 3$ pertanyaan $=91-120$

2. Baik $=10$ Responden $\times 3$ skala $\times 3$ pertanyaan $=$ $61-90$

3. Kurang Baik $=10$ Responden $\times 2$ skala $\times 3$ pertanyaan $=31-60$

4. Sangat Kurang Baik $=10$ Responden $x 1$ skala $x$ 3 pertanyaan $=0-30$

Tabel 5. Skala Likert Reliability

\begin{tabular}{|c|l|c|}
\hline No & \multicolumn{1}{|c|}{ Kategori } & Skala \\
\hline 1 & Sangat Baik & $91-120$ \\
\hline 2 & Baik & $61-90$ \\
\hline 3 & Kurang Baik & $31-60$ \\
\hline 4 & Sangat Kurang Baik & $0-30$ \\
\hline
\end{tabular}

Berikut hasil pengujian dari aspek Reliability ISO 9126 dari 10 responden sistem informasi bank sampah. Dari hasil pengujian mendapat nilai total skala 111 yang berarti hasil pengujian Reliability termasuk kisaran skala 91-120 yaitu sangat baik.

Tabel 6. Hasil Pengujian Aspek Reliability

\begin{tabular}{|c|c|c|c|c|}
\hline Responden & P 2.1 & P 2.2 & P 2.3 & Total \\
\hline 1 & 4 & 4 & 4 & 12 \\
\hline 2 & 4 & 4 & 3 & 11 \\
\hline 3 & 4 & 3 & 4 & 11 \\
\hline 4 & 4 & 4 & 3 & 11 \\
\hline 5 & 4 & 4 & 4 & 12 \\
\hline 6 & 4 & 4 & 4 & 12 \\
\hline 7 & 4 & 4 & 3 & 11 \\
\hline 8 & 3 & 4 & 4 & 11 \\
\hline 9 & 3 & 3 & 3 & 9 \\
\hline 10 & 3 & 4 & 4 & 11 \\
\hline \multicolumn{4}{|c|}{ Total Skala } & 111 \\
\hline
\end{tabular}

3. Pengujian aspek usability

Berikutnya dasar pengujian kualitas sistem informasi aspek Usability terdiri dari 4 pertanyaan dengan skala likert dilakukan perhitungan sebagai berikut.

1. Sangat Baik $=10$ Responden $\times 4$ skala $\times 4$ pertanyaan $=121-160$

2. Baik $=10$ Responden $\times 3$ skala $\times 4$ pertanyaan $=$ $81-120$

3. Kurang Baik $=10$ Responden $\times 2$ skala $\times 4$ pertanyaan $=41-80$

4. Sangat Kurang Baik $=10$ Responden $x 1$ skala $x$ 4 pertanyaan $=0-40$
Tabel 7. Skala Likert Usability

\begin{tabular}{|c|l|c|}
\hline No & \multicolumn{1}{|c|}{ Kategori } & Skala \\
\hline 1 & Sangat Baik & $121-160$ \\
\hline 2 & Baik & $81-120$ \\
\hline 3 & Tidak Baik & $41-80$ \\
\hline 4 & Sangat Tidak Baik & $0-40$ \\
\hline
\end{tabular}

Berikut hasil pengujian dari aspek Usability ISO 9126 dari 10 responden sistem informasi bank sampah. Dari hasil pengujian mendapat nilai total skala 147 yang berarti hasil pengujian Usability termasuk kisaran skala $120-160$ yaitu sangat baik.

Tabel 8. Hasil Pengujian Aspek Usability

\begin{tabular}{|c|c|c|c|c|c|}
\hline Responden & P 3.1 & P 3.2 & P 3.3 & P 3.4 & Total \\
\hline 1 & 4 & 4 & 3 & 3 & 14 \\
\hline 2 & 4 & 4 & 4 & 3 & 15 \\
\hline 3 & 4 & 4 & 3 & 3 & 14 \\
\hline 4 & 4 & 4 & 3 & 4 & 15 \\
\hline 5 & 3 & 4 & 4 & 3 & 14 \\
\hline 6 & 4 & 3 & 3 & 4 & 14 \\
\hline 7 & 4 & 4 & 3 & 4 & 15 \\
\hline 8 & 4 & 4 & 4 & 4 & 16 \\
\hline 9 & 4 & 4 & 3 & 3 & 14 \\
\hline 10 & 4 & 4 & 4 & 4 & 16 \\
\hline \multicolumn{7}{|c|}{} \\
\hline
\end{tabular}

\section{Pengujian aspek Efficiency}

Berikutnya dasar pengujian kualitas sistem informasi aspek Efficiency terdiri dari 2 pertanyaan dengan skala likert dilakukan perhitungan sebagai berikut.

1. Sangat Baik $=10$ Responden $\times 4$ skala $\times 2$ pertanyaan $=61-80$

2. Baik $=10$ Responden $\times 3$ skala $\times 2$ pertanyaan $=$ $41-60$

3. Kurang Baik $=10$ Responden $\times 2$ skala $\times 2$ pertanyaan $=21-40$

4. Sangat Kurang Baik $=10$ Responden $\times 1$ skala $x$ 2 pertanyaan $=0-20$

Tabel 9. Skala Likert Efficiency

\begin{tabular}{|c|l|c|}
\hline No & \multicolumn{1}{|c|}{ Kategori } & Skala \\
\hline 1 & Sangat Baik & $61-80$ \\
\hline 2 & Baik & $41-60$ \\
\hline 3 & Tidak Baik & $21-40$ \\
\hline 4 & Sangat Tidak Baik & $0-20$ \\
\hline
\end{tabular}

Berikut hasil pengujian dari aspek Efficiency ISO 9126 dari 10 responden sistem informasi bank sampah. Dari hasil pengujian mendapat nilai total skala 69 yang berarti hasil pengujian Efficiency termasuk kisaran skala 60 - 80 yaitu sangat baik. 
Tabel 10. Hasil Pengujian Aspek Efficiency

\begin{tabular}{|c|c|c|c|}
\hline Responden & P 4.1 & P 4.2 & Total \\
\hline 1 & 3 & 3 & 6 \\
\hline 2 & 3 & 3 & 6 \\
\hline 3 & 4 & 3 & 7 \\
\hline 4 & 4 & 3 & 7 \\
\hline 5 & 4 & 4 & 8 \\
\hline 6 & 4 & 3 & 7 \\
\hline 7 & 3 & 4 & 7 \\
\hline 8 & 4 & 3 & 7 \\
\hline 9 & 4 & 3 & 7 \\
\hline 10 & 4 & 3 & 7 \\
\hline \multicolumn{5}{|c|}{ Total Skala } & 69 \\
\hline
\end{tabular}

\section{Pengujian aspek Maintainability}

Berikutnya dasar pengujian kualitas sistem informasi aspek Maintainability terdiri dari 4 pertanyaan dengan skala likert dilakukan perhitungan sebagai berikut.

1. Sangat Baik $=10$ Responden $\times 4$ skala $\times 4$ pertanyaan $=121-160$

2. Baik $=10$ Responden $\times 3$ skala $\times 4$ pertanyaan $=$ $81-120$

3. Kurang Baik $=10$ Responden $\times 2$ skala $\times 4$ pertanyaan $=41-80$

4. Sangat Kurang Baik $=10$ Responden $x 1$ skala $x$ 4 pertanyaan $=0-40$

Tabel 11. Skala Likert Maintainability

\begin{tabular}{|c|l|c|}
\hline No & \multicolumn{1}{|c|}{ Kategori } & Skala \\
\hline 1 & Sangat Baik & $121-160$ \\
\hline 2 & Baik & $81-120$ \\
\hline 3 & Tidak Baik & $41-80$ \\
\hline 4 & Sangat Tidak Baik & $0-40$ \\
\hline
\end{tabular}

Berikut hasil pengujian dari aspek Maintainability ISO 9126 dari 10 responden sistem informasi bank sampah. Dari hasil pengujian mendapat nilai total skala 137 yang berarti hasil pengujian Maintainability termasuk kisaran skala 121 - 160 yaitu sangat baik.

Tabel 12. Hasil Pengujian Aspek Maintainability

\begin{tabular}{|c|c|c|c|c|c|}
\hline Responden & P 5.1 & P 5.2 & P 5.3 & P 5.4 & Total \\
\hline 1 & 3 & 3 & 3 & 3 & 12 \\
\hline 2 & 2 & 3 & 2 & 3 & 10 \\
\hline 3 & 4 & 4 & 4 & 4 & 16 \\
\hline 4 & 4 & 4 & 3 & 3 & 14 \\
\hline 5 & 3 & 4 & 4 & 2 & 13 \\
\hline 6 & 4 & 3 & 4 & 4 & 15 \\
\hline 7 & 4 & 4 & 3 & 2 & 13 \\
\hline 8 & 4 & 4 & 4 & 4 & 16 \\
\hline 9 & 4 & 4 & 3 & 2 & 13 \\
\hline 10 & 4 & 4 & 4 & 3 & 15 \\
\hline \multicolumn{7}{|c|}{ Total Skala } & 137 \\
\hline
\end{tabular}

6. Pengujian aspek Portability

Berikutnya dasar pengujian kualitas sistem informasi aspek Portability terdiri dari 2 pertanyaan dengan skala likert dilakukan perhitungan sebagai berikut.

1. Sangat Baik $=10$ Responden $\times 4$ skala $\times 2$ pertanyaan $=61-80$

2. Baik $=10$ Responden $\times 3$ skala $\times 2$ pertanyaan $=$ $41-60$

3. Kurang Baik $=10$ Responden $\times 2$ skala $\times 2$ pertanyaan $=21-40$

4. Sangat Kurang Baik $=10$ Responden $x 1$ skala $x$ 2 pertanyaan $=0-20$

Tabel 13. Skala Likert Portability

\begin{tabular}{|c|l|c|}
\hline No & \multicolumn{1}{|c|}{ Kategori } & Skala \\
\hline 1 & Sangat Baik & $61-80$ \\
\hline 2 & Baik & $41-60$ \\
\hline 3 & Tidak Baik & $21-40$ \\
\hline 4 & Sangat Tidak Baik & $0-20$ \\
\hline
\end{tabular}

Berikut hasil pengujian dari aspek Portability ISO 9126 dari 10 responden sistem informasi bank sampah. Dari hasil pengujian mendapat nilai total skala 55 yang berarti hasil pengujian Portability termasuk kisaran skala 41 - 60 yaitu baik.

Tabel 14. Hasil Pengujian Aspek Portability

\begin{tabular}{|c|c|c|c|}
\hline Responden & P 6.1 & P 6.2 & Total \\
\hline 1 & 2 & 2 & 4 \\
\hline 2 & 2 & 2 & 4 \\
\hline 3 & 2 & 3 & 5 \\
\hline 4 & 3 & 3 & 6 \\
\hline 5 & 3 & 2 & 5 \\
\hline 6 & 4 & 4 & 8 \\
\hline 7 & 4 & 3 & 7 \\
\hline 8 & 4 & 4 & 8 \\
\hline 9 & 2 & 2 & 4 \\
\hline 10 & 2 & 2 & 4 \\
\hline \multicolumn{5}{|c|}{ Total Skala } & 55 \\
\hline
\end{tabular}

\section{KESIMPULAN DAN SARAN}

Berdasarkan hasil pengujian Blackbox Testing dan pengujian kualitas sistem informasi menggunakan ISO 9126 dapat disimpulkan, bahwa hasil dari pengujian Blackbox Testing perancangan sistem informasi bank sampah menggunakan framework codeigniter dan bootsrap menggunakan metode prototype yaitu dengan menguji fungsional tanpa melihat alur eksekusi program, namun cukup dengan memperhatikan apakah setiap fungsi sudah berjalan dengan baik mendapatkan hasil 
bahwa sistem informasi bank sampah berjalan dengan lancar. Sedangkan pengujian kualitas dengan ISO 9126 dari enam aspek rata-rata hasil uji menghasilkan kategori sangat baik.

Saran dalam penelitian ini sistem informasi dapat dibuatkan aplikasi berbasis mobile dan untuk pengujian dapat menambah responden agar lebih efektif hasilnya.

\section{UCAPAN TERIMA KASIH}

Ucapan terimakasih penulis sampaikan kepada pengurus bank sampah RW.04 Kel.Cipinang Besar Selatan beserta anggota bank sampah yang telah ikut berkontribusi dalam penelitian ini serta mahasiswa yang telah ikut membantu peneliti.

\section{DAFTAR PUSTAKA}

[1] Utami, E. (2013). Buku Panduan Sistem Bank Sampah \& 10 Kisah Sukses. Jakarta: Yayasan Unilever.

[2] Pratama, I. P. (2014). Sistem Informasi Dan Implementasinya (1st ed.). Bandung: Informatika.

[3] Sidik. Betha. (2012). Framework Codelgniter. Bandung: Informatika.

[4] Zakir, A. (2016). Rancang Bangun Responsive Web Layout dengan Menggunakan Bootstrap Framework. Jurnal Informatika dan Teknologi Jaringan, 7.

[5] Rosa A.S, M Shalahuddin. (2013). Pembelajaran Rekayasa Perangkat Lunak (Terstruktur dan Berorientasi Objek). Bandung: Informatika.

[6] Weber, R. (1999). Information System Control and Audit. New Jersey: Prentice Hall. 